International Journal of Zoological Research 5 (1): 27-41, 2009

ISSN 1811-9778

(C) 2009 Academic Journals Inc.

\title{
Insectivorous Birds and Environmental Factors Across an Edge-Interior Gradient in Tropical Rainforest of Malaysia
}

\author{
Hossein Varasteh Moradi, Mohamed Zakaria, Abdullah B. Mohd, Ebil Yusof \\ Faculty of Forestry, Universiti Putra Malaysia, 43400 UPM, Serdang, \\ Selangor Darul Ehsan, Malaysia
}

\begin{abstract}
The study objectives were to test: (1) the effects of the edge-interior gradient on under storey insectivorous bird abundance, density and diversity; (2) effects of environmental variables along an edge-interior gradient at population level (i.e., on each sub-guilds and species abundance); (3) possible effects of environmental structure along an edge-interior gradient at community level (i.e., species richness, diversity and total abundance). Fifteen hundred and four birds belonging to 49 species were recorded. Species composition differed along the edge-interior gradient at the guild and species level. The composition of insectivorous birds was correlated with the latter measured environmental variables. Based on bird-habitat associations along the edge-interior gradient, two groups were distinguished. Arboreal foliage gleaning insectivores were positively correlated with ground cover, light intensity, shrub cover and percent of shrub cover between 0.5 and $2 \mathrm{~m}$ high. While terrestrial insectivores, were sensitive to the forest edge and could indicate the quality of forest interior habitats associated with high humidity, dense canopy cover and deep litter depth. Forest remnants in the lowlands of Peninsular Malaysia that have a deep leaf litter layer, a dense canopy cover and high relative humidity are able to support insectivorous species that are sensitive to edge effects. As such these forests have important conservation value.
\end{abstract}

Key words: Density, diversity, forest edge, community analysis

\section{INTRODUCTION}

Tropical rain forests are the planet's most biologically diverse ecosystems. Degradation of tropical forests through logging, isolation, fragmentation and isolation is widely continuing. In most tropical regions, forest habitat is being cleared and isolated by the rapid proliferation of small and large clearings. In spite of several researches on this problem, the impacts of such disturbances on the fauna and flora especially birds have been poorly comprehended (Hill and Hamer, 2004). Forest fragmentation and forest isolation affects the distribution and abundance of organisms by reducing the amount and proximity of remnant patches of suitable habitat and increasing the amount of edges (Maina and Jackson, 2003). The majority of recent studies on the effects of habitat loss or degradation of various Southeast Asian biotas have focused on lowland rain forest habitat (Soh et al., 2005). Although many lowland species are prone to extinction due to intense logging pressure, little attention has been focused on edge effect. Edges can alter abiotic processes such as microclimate, light intensity, and hydrology (Sisk et al., 1997) and biotic factors such as predator communities (Maina and Jackson, 2003), habitat structure (Canaday, 1996) and food availability (Barlow and Peres, 2004). These changes in conditions at edges can be associated with changes in abundance, density and diversity of birds due to changes in their demographic rates (Paton, 1994; Donovan et al., 1997), or through

Corresponding Author: Mohamed Zakaria, Faculty of Forestry, Universiti Putra Malaysia, 43400 UPM, Serdang, Selangor Darul Ehsan, Malaysia Tel: +60-19-269-0355 
behavioural avoidance of or attraction to the edge (Lidicker, 1999). Fragmentation generally increases the amount of edge per unit land area and species that are adversely affected by edges can experience shrink of effective area of suitable habitat (Maina and Jackson, 2003) which can lead to high probability of extinction in fragmented landscapes (Woodroffe and Ginsberg, 1998). Avian species may respond to one or combination of these changes in the landscape as a result of different biological mechanisms (Donovan et al., 1997). Species that require forest interior may avoid edges due to altered microclimate, vegetation structure because of variation of vegetation species composition and structure with distance from edge or high density of predators or brood parasites (Stephens et al., 2003).

Few studies have examined bird communities in Southeast Asia forest isolates. Besides, less is known about the direct effects of edge on tropical forest bird community especially insectivorous species. Diet plays an important role in determining a species' response to disturbance. Insectivorous bird species are the most sensitive to forest disturbances (Fimbel et al., 2001). Food supply for insectivores has been shown to vary in fragment size as a result of edge effects, because invertebrates, especially surface dwellers are prone to desiccation and may not survive well in edge habitat, which is often warmer and drier than the forest interior (Zanette et al., 2000).

The main objectives of this research were to test: (1) the effects of the edge-interior gradient on under storey insectivorous bird abundance, density and diversity; (2) effects of environmental variables along an edge-interior gradient at population level (i.e., on each sub-guilds and species abundance); (3) possible effects of environmental structure along an edge-interior gradient at community level (i.e., species richness, diversity and total abundance).

\section{MATERIALS AND METHODS}

\section{Study Site}

The study was conducted in Ayer Hitam Forest Reserve, Puchong, Selangor, Malaysia between April 2007 and July 2008 . The area is located at about $3^{\circ} 00.00^{\prime} \mathrm{N}$ to $3^{\circ} 02.20^{\prime} \mathrm{N}$ and $101^{\circ} 37.90^{\prime} \mathrm{E}$ to $101^{\circ} 40.00^{\prime} \mathrm{E}$, approximately $20 \mathrm{~km}$ Southwest of Kuala Lumpur. The Ayer Hitam Forest Reserve is surrounded by development, making it an isolated patch of forest in the middle of modern infrastructure and society of Puchong, Kinrara, Seri Kembangan, Serdang and the Multimedia Super Corridor (MSC) (Fig. 1). The study area is an isolated lowland dipterocarp rainforest. This forest suffers by surrounding highways and housing areas. It was originally about 3500 ha in area. However, in 1997, the forest on the eastern side of Puchong was excised for housing projects and highways and the forest area was decreased to 1248 ha. This forest is the only lowland green lung left in the Klang Valley for now and the generations to come (Varasteh Moradi et al., 2008).

\section{Bird Sampling}

The point-count sampling method (Bibby et al., 2000) was used to survey under storey insectivorous species abundance at each of the 93 survey points in ten visits between April 2007 and July 2008. The fourteen parallel transects were placed across the gradient of distance from the forest edge at $200 \mathrm{~m}$ intervals (to minimize the risk of counting the same individual twice) (Antongiovanni and Metzer, 2005) beginning approximately $25 \mathrm{~m}$ from the forest edge. Data were collected at each of the 93 sampling points where the transects intersected; distance 1 refers to the fourteen points closest to the edge, distances 2, 3 and 4 the next three set of fourteen sampling points 200,400 and $600 \mathrm{~m}$ farther from the forest edge, distance 5 refers to thirteen sampling points $800 \mathrm{~m}$ farther from the forest edge, distance 6 refers to eleven sampling points $1000 \mathrm{~m}$ farther from the forest edge and distance 7 refers to thirteen sampling points farthest (about $1200 \mathrm{~m}$ ) from the forest edge. To avoid time-of-day biases, the points were visited in reverse order on different visits. Birds were counted at each census station point for a period of $10 \mathrm{~min}$ (Marsden et al., 2001). Birds occurring within $25 \mathrm{~m}$ 


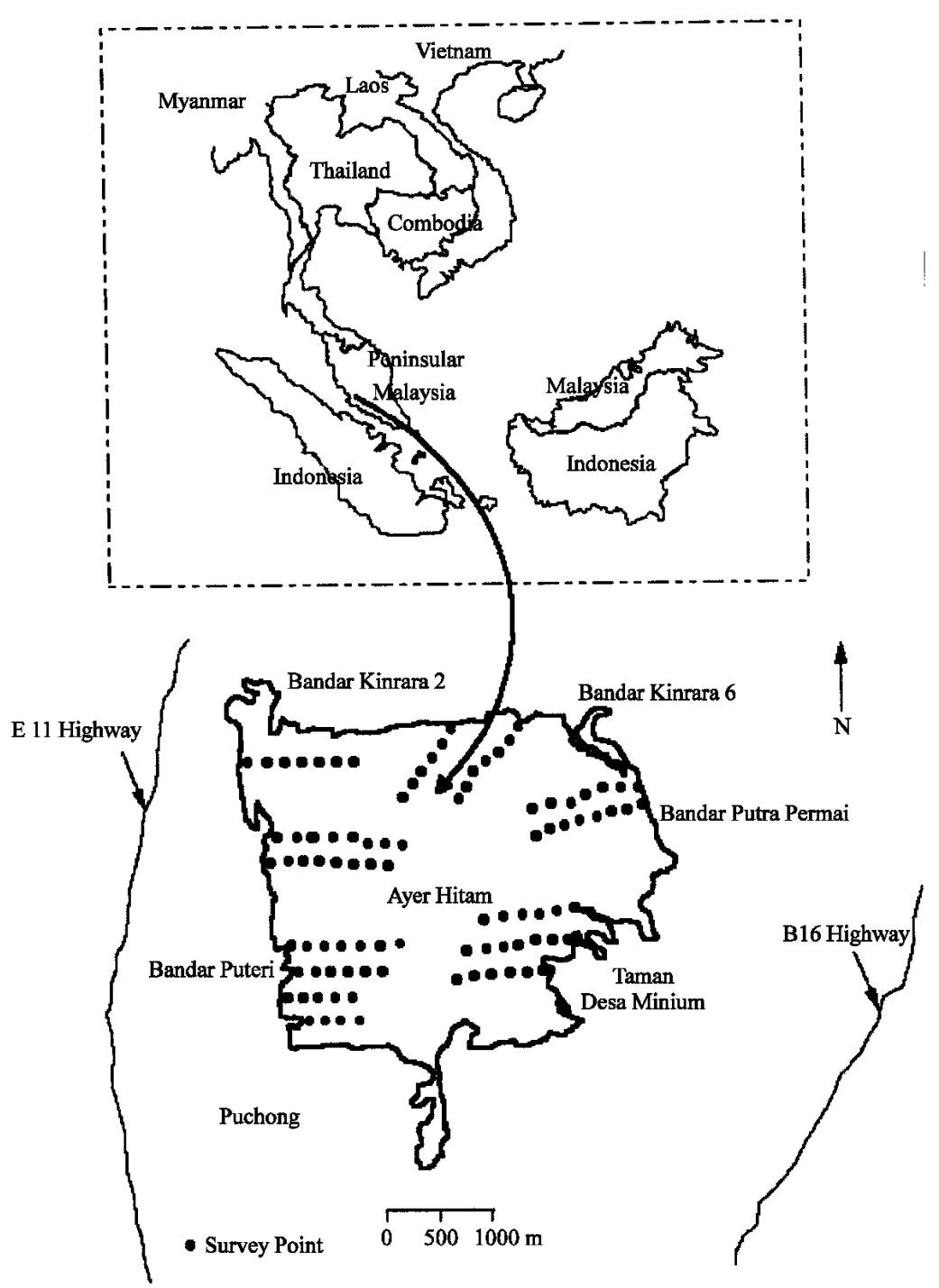

Fig. 1: Map showing the position of Ayer Hitam Forest Reserve

fixed radius of each station were recorded because it was often not possible to identify species past this distance (Watson et al., 2004). Only species sighted within the point count area were recorded as present. Calls were used to locate birds and to aid identification. Bird surveys were carried out between 0730 and $1030 \mathrm{~h}$ and only in the absence of rain or heavy mist. All point counts were conducted by one observer to minimise observer effects.

\section{Microhabitat and Microclimate Measurements}

Twenty six microhabitat and microclimate variables were recorded at each point to determine the effects of environmental variables on insectivorous birds. In each point, vegetation was measured within a $25 \mathrm{~m}$ radius (Castelletta et al., 2005). The variables recorded were: the distance from the forest edge (DIS), the slope (SLO), the temperature (TEM), the humidity (HUM), the light intensity (LUX), 
the number (NDT) and d.b.h (DDT) of dead trees, the Number of Palm Trees (NPT), the Leaf Litter Depth (LDP), the percent of Leaf Litter Cover (LPC), the basal area (BSL), the Canopy Cover (CCV), the ground cover $(\mathrm{GCV})$, the under storey shrub cover ( $\mathrm{SHC}$ ), the percent of shrub cover between 0.5 and $2 \mathrm{~m}$ high (PSH2), the percent of shrub cover between 2 and $6 \mathrm{~m}$ high (PSH6), the number of trees 6-10 $\mathrm{m}$ high (NT6), the number of trees higher than $10 \mathrm{~m}$ (NT10), the number of tree saplings with d.b.h less than $2 \mathrm{~cm}$ (NT2), the number of trees with d.b.h $5-10 \mathrm{~cm}$ (NT5), the number of tree species (NTS), the number of tree with d.b.h $20-30 \mathrm{~cm}$ (NT20), the number of tree with d.b.h $30-50 \mathrm{~cm}$ (NT30), the number of tree with d.b.h more than $50 \mathrm{~cm}$ (NT50), the number of Melastoma malabathricum shrubs (MM) and the number of Agrostistachys longifolia trees (AL).

\title{
Data Analysis
}

Prior to conducting statistical analysis, each variable was tested for deviations from the normal distribution using Kolmogorov-Smimov test for equality of variances. Differences in total number of individuals, species and diversity per plot between the seven different distances from the forest edge were tested with General Linear Models (GLM), to compensate for differences in sample size. A post-hoc Tukey's test was used to determine which forest edge-interior gradient types differed significantly from which for the tested variables. When the data were not normally distributed, or standard deviations between factors differed too much to apply GLM, non-parametrical Kruskal-Wallis and Mann-Whitney U-test were used.

Using Canoco 4.5 software (Ter-Braak and Smilauer, 2002) the relation between insectivorous species abundances, insectivorous species diversity and habitat variables was explored. The linear constrained redundancy ordination (RDA) (Ter-Braak and Smilauer, 2002) was performed to detect insectivorous bird species response to gradients in environmental variables. RDA is an interesting extension of PCA that explicitly models response variables as a function of explanatory variables (Zuur et al., 2007). The default by species scaling method was employed as the main interest was in the ordination of individual species with respect to one another and the environmental variables. The significance of the RDA was calculated using the Monte Carlo permutation tests with 499 permutations. To reduce the influence that the most abundant species might have in the ordination analysis, the abundance of each species was log-transformed (Jongman et al., 1995). To determine which explanatory variables are more important, RDA analysis using a forward selection procedure was applied. Also the default attribute plots based on sample scores was used to display the variability in the species composition (diversity index values) related to explanatory variables.

All statistical tests were performed using Minitab 15 except for ordination analysis performed with Canoco 4.5., diversity index values using Ecological Methodology software and density estimates using the DISTANCE 5.0 program. In text and tables, values are Means \pm SD. Statistical significance for all analysis was set at $\alpha=0.05$.

\section{RESULTS}

\begin{abstract}
Abundance and Diversity
Across all visits to all sampling points, 1504 observations of 49 different under storey insectivores were detected (Appendix). As shown in Table 1, there was no effect of distance gradient on the insectivore species abundance $(\mathrm{K}-\mathrm{W}, \mathrm{H}=6.79, \mathrm{p}=0.341)$. Among the four insectivore subguilds, two showed a significant difference in the numbers observed. Terrestrial insectivores had a significantly higher number in distances 6 and $7(\mathrm{~K}-\mathrm{W}, \mathrm{H}=14.44, \mathrm{p}=0.025)$. Arboreal foliage gleaning insectivores had a significantly higher number in distance $1(\mathrm{~K}-\mathrm{W}, \mathrm{H}=19.92, \mathrm{p}=0.006)$. There was also significant effect of distance gradient at the species level. Among the 49 insectivorous species, five showed a significant difference in the numbers observed. Three insectivores for which abundance was
\end{abstract}


significantly high close to the edge were Striped Tit-babbler (Macronous gularis) with the higher number of observation at distance $1(\mathrm{~K}-\mathrm{W}, \mathrm{H}=19.18, \mathrm{p}=0.004)$, Fluffy-backed Tit-babbler (Macronous ptilosus) with the higher number of observation at distance $2(\mathrm{~K}-\mathrm{W}, \mathrm{H}=17.10$, $\mathrm{p}=0.009$ ) and Plaintive Cuckoo (Cacomantis merulimus) with the higher number of observation at distance $1(\mathrm{~K}-\mathrm{W}, \mathrm{H}=13.52, \mathrm{p}=0.041)$. Two insectivores for which abundance increased significantly with increasing distance from the forest edge were short-tailed Babbler (Malacocincla malaccensis) with the higher number of observation at distances 6 and $7(\mathrm{~K}-\mathrm{W}, \mathrm{H}=15.11, \mathrm{p}=0.019)$ and white-rumped Shama (Copsychus malabaricus) with the higher number of observation at distance 3 ( $\mathrm{K}-\mathrm{W}, \mathrm{H}=15.69, \mathrm{p}=0.016$ ). There was also strong effect of distances gradient on the diversity indices. The number of insectivore species (GLM, $\mathrm{F}=2.25, \mathrm{p}=0.032$ ) and Simpson evenness index (GLM, $F=6.45, p=0.000$ ) showed significant differences along edge-interior gradient. The MannWhitney U-test revealed that the number of insectivorous bird species and Simpson evenness index had significantly higher value at distances 3 and 2, respectively.

\section{Density Estimates}

Density analysis were presented based on the insectivorous community as whole, the four insectivore sub-guilds and only for the fifteen insectivorous species (because of insufficient number of observation for all insectivorous species). At these levels of aggregation, the number of individual observations was sufficient to generate robust density estimates for birds (Table 2). Under storey insectivores presented at highest density at distance $1\left(22.31 \pm 5.52\right.$ individuals ha $\left.{ }^{-1}\right)$. Referring to 
Int. J. Zool. Res., 5 (1): 27-41, 2009

Table 2: Density estimates (individuals per ha ${ }^{-1}$ ) $\pm \% \mathrm{SE}$ and $95 \%$ confidence intervals for under storey insectiv ores in relation to different distances from the forest edge

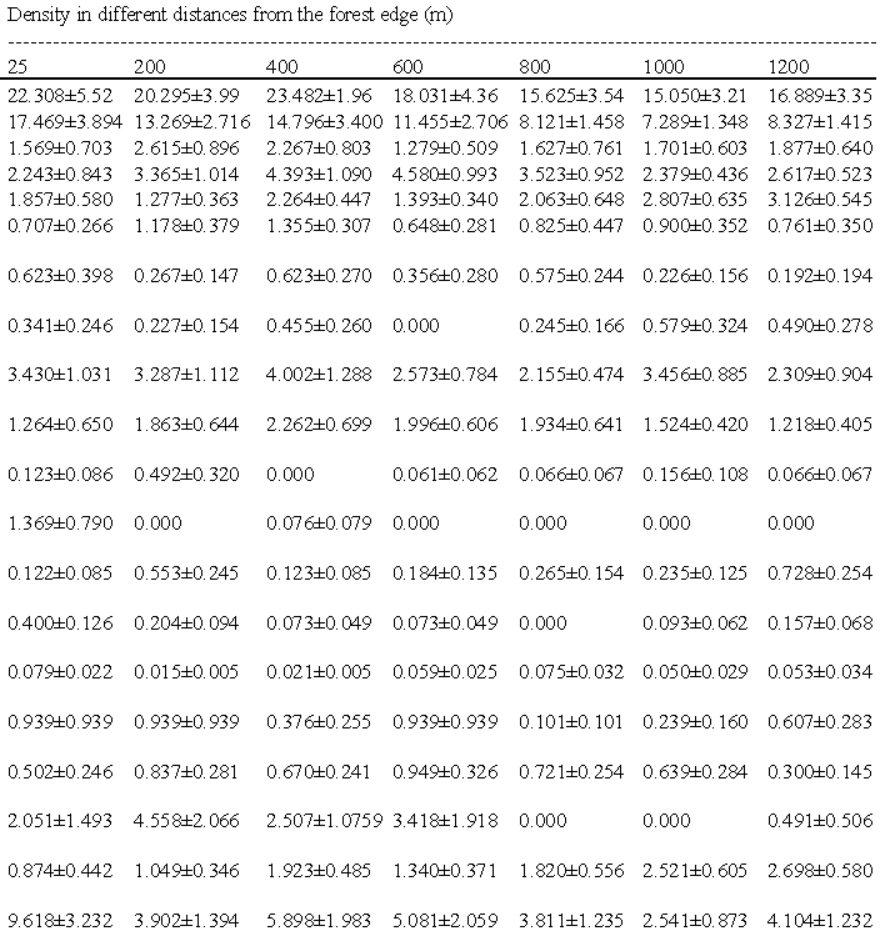

Table 2 the four sub-guilds had different density response to different distances from edge. The highest density and the lowest density of arboreal foliage gleaning insectivores was present at distance $1\left(17.47 \pm 3.89\right.$ individuals $\left.\mathrm{ha}^{-1}\right)$ and distance $6\left(7.29 \pm 1.35\right.$ individuals $\left.\mathrm{ha}^{-1}\right)$, respectively. Sallying insectivores occurred at highest density and lowest density at distance $4\left(4.58 \pm 0.99\right.$ individuals ha $\left.{ }^{-1}\right)$ and distance $1\left(2.24 \pm 0.84\right.$ individuals $\left.\mathrm{ha}^{-1}\right)$, respectively. Bark gleaning insectivores had the highest density at distance $2\left(2.615 \pm 0.89\right.$ individuals $\left.\mathrm{ha}^{-1}\right)$ and the lowest density at distance $4\left(1.28 \pm 0.51\right.$ individuals $\left.\mathrm{ha}^{-1}\right)$. While terrestrial insectivore had the highest density at distance $7\left(3.13 \pm 0.54\right.$ individuals $\left.\mathrm{ha}^{-1}\right)$ and lowest density at distance $2\left(1.28 \pm 0.36\right.$ individuals $\left.\mathrm{ha}^{-1}\right)$.

At the species level, the insectivores had different density response to the edge. Notable were density estimates for Striped Tit-babbler $\left(9.62 \pm 3.23\right.$ individuals $\mathrm{ha}^{-1}$ at distance 1 and $2.54 \pm 0.87$ individuals $\mathrm{ha}^{-1}$ at distance 6), Fluffy-backed Tit-babbler $\left(4.56 \pm 2.07\right.$ individuals $^{-1}$ at distance 2 and 0.00 individuals $\mathrm{ha}^{-1}$ at distances 5 and 6), Maroon Woodpecker (Blythipicus rubiginosus) $\left(0.73 \pm 0.25\right.$ individuals $\mathrm{ha}^{-1}$ at distance 7 and $0.12 \pm 0.08$ individuals ha ${ }^{-1}$ at distance 1$)$, Plaintive Cuckoo $\left(0.40 \pm 0.13\right.$ individuals ha ${ }^{-1}$ at distance 1 and 0.00 individuals ha ${ }^{-1}$ at distance 5) and Short-tailed Babbler (2.70 \pm 0.58 individuals ha ${ }^{-1}$ at distance 7 and $0.87 \pm 0.44$ individuals ha ${ }^{-1}$ at distance 1).

\section{Effects of Different Environmental Variables at the Population Level}

The correlation between environmental variables and the abundances of insectivorous sub-guilds and individual species were tested using stepwise multiple regressions. $\mathrm{R}^{2}$ values indicated that some of environmental variables had affected to the abundances of insectivores species. At the sub-guild level, birds different response to the environmental variables (Table 3). Terrestrial insectivores were 
Int. J. Zool. Res., 5 (1): 27-41, 2009

Table 3: Habitat variables measured along edge-interior gradient

Different distances from the forest edge ( $\mathrm{m}$ )

\begin{tabular}{|c|c|c|c|c|c|c|c|c|c|c|}
\hline \multirow{2}{*}{$\begin{array}{l}\text { Explanatory } \\
\text { variables }\end{array}$} & & \multirow{2}{*}{\multicolumn{2}{|c|}{$\mathrm{F}$ or $\mathrm{H} \mathrm{p}$-value }} & \multirow[b]{2}{*}{ Test } \\
\hline & 25 & 200 & 400 & 600 & 800 & 1000 & 1200 & & & \\
\hline TEM & $24.83 \pm 1.26^{4}$ & $24.49 \pm 0.98^{\mathrm{ab}}$ & $24.27 \pm 0.97^{b}$ & $24.30 \pm 1.06^{b}$ & $24.21 \pm 1.17^{b}$ & $24.35 \pm 1.30^{6}$ & $24.53 \pm 1.52^{\mathrm{ab}}$ & $4.32^{\circ}$ & 0.000 & GLM \\
\hline HUM & $96.16 \pm 4.39^{b}$ & $96.89 \pm 3.64^{4 b}$ & $97.65 \pm 2.74^{2}$ & $97.21 \pm 3.33^{\text {ab }}$ & $97.51 \pm 3.05^{\circ}$ & $97.21 \pm 3.39^{\mathrm{ab}}$ & $96.84 \pm 3.75^{\text {ab }}$ & $2.78^{\circ}$ & 0.011 & GLM \\
\hline LUX & $117.8 \pm 113.5^{2}$ & $24.35 \pm 18.6^{b}$ & $23.46 \pm 17.03^{b}$ & $24.97 \pm 11.63^{b}$ & $21.10 \pm 13.00^{b}$ & $23.72 \pm 9.55^{b}$ & $40.10 \pm 37.80^{b}$ & $19.96^{\circ}$ & 0.003 & $\mathrm{~K}-\mathrm{W}$ \\
\hline SLO & $3.870 \pm 2.83$ & $4.460 \pm 1.36$ & $4.930 \pm 2.91$ & $4.540 \pm 2.25$ & 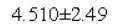 & $4.000 \pm 3.82$ & $3.850 \pm 2.59$ & 0.32 & 0.926 & GLM \\
\hline BSL & $0.380 \pm 0.47$ & $0.180 \pm 0.18$ & $0.220 \pm 0.36$ & $0.320 \pm 0.34$ & $0.250 \pm 0.14$ & $0.190 \pm 0.13$ & $0.210 \pm 0.19$ & 4.42 & 0.62 & $\mathrm{~K}-\mathrm{W}$ \\
\hline NT 10 & $2.240 \pm 1.29$ & $2.790 \pm 0.77$ & $2.690 \pm 1.04$ & $2.940 \pm 0.30$ & $3.030 \pm 0.21$ & 2. $940 \pm 0.23$ & $2.830 \pm 0.78$ & 3.22 & 0.780 & $\mathrm{~K}-\mathrm{W}$ \\
\hline NT2 & $2.900 \pm 1.14$ & $3.070 \pm 0.92$ & $2.760 \pm 1.11$ & $3.120 \pm 0.25$ & $3.280 \pm 0.32$ & $2.990 \pm 0.93$ & $2.880 \pm 0.91$ & 3.65 & 0.723 & $\mathrm{~K}-\mathrm{W}$ \\
\hline NT2O & $0.400 \pm 0.16$ & $0.510 \pm 0.20$ & $0.360 \pm 0.12$ & $0.480 \pm 0.19$ & $0.580 \pm 0.22$ & $0.500 \pm 0.19$ & $0.530 \pm 0.24$ & 10.93 & 0.091 & $\mathrm{~K}-\mathrm{W}$ \\
\hline NT 30 & $0.460 \pm 0.21$ & $0.380 \pm 0.15$ & $0.440 \pm 0.17$ & $0.430 \pm 0.19$ & $0.450 \pm 0.17$ & $0.400 \pm 0.17$ & $0.510 \pm 0.22$ & 3.79 & 0.705 & $\mathrm{~K}-\mathrm{W}$ \\
\hline NT 50 & $0.440 \pm 0.17$ & $0.340 \pm 0.10$ & $0.340 \pm 0.10$ & $0.390 \pm 0.16$ & $0.350 \pm 0.11$ & $0.350 \pm 0.12$ & $0.340 \pm 0.13$ & 6.98 & 0.323 & $\mathrm{~K}-\mathrm{W}$ \\
\hline NPT & $2.410 \pm 1.17$ & $2.630 \pm 1.02$ & $2.440 \pm 1.16$ & $2.510 \pm 1.00$ & $2.570 \pm 1.03$ & $2.790 \pm 0.85$ & $2.660 \pm 0.74$ & 2.36 & 0.884 & $\mathrm{~K}-\mathrm{W}$ \\
\hline NDT & $1.870 \pm 1.23$ & $2.310 \pm 1.13$ & $2.560 \pm 0.67$ & $2.050 \pm 1.17$ & $1.640 \pm 1.30$ & $2.640 \pm 0.24$ & 21 & 8.13 & 0.229 & $\mathrm{~K}-\mathrm{W}$ \\
\hline DDT & $1.120 \pm 0.65^{b}$ & $1.200 \pm 0.52^{b}$ & $1.360 \pm 0.39^{4 b}$ & $1.060 \pm 0.55^{\text {sb }}$ & $0.912 \pm 0.61^{\text {tb }}$ & $1.610 \pm 0.25^{2}$ & $0.890 \pm 0.63^{2 b}$ & $13.09^{\circ}$ & 0.042 & $\mathrm{~K}-\mathrm{W}$ \\
\hline $\mathrm{SHC}$ & $2.720 \pm 1.08^{2}$ & $1.210 \pm 1.28^{b}$ & $1.360 \pm 1.29^{b}$ & $0.850 \pm 1.10^{b}$ & $0.860 \pm 1.05^{b}$ & $1.220 \pm 1.28^{b}$ & $1.010 \pm 1.12^{b}$ & $23.47^{\circ}$ & 0.001 & $\mathrm{~K}-\mathrm{W}$ \\
\hline LDP & $0.850 \pm 0.92^{b}$ & $1.080 \pm 1.26^{2}$ & $1.070 \pm 1.36^{2}$ & $1.030 \pm 1.41^{\text {sb }}$ & $1.120 \pm 1.30^{*}$ & $0.960 \pm 1.29^{\mathrm{sb}}$ & $1.110 \pm 1.32^{*}$ & $14.07^{\circ}$ & 0.029 & $\mathrm{~K}-\mathrm{W}$ \\
\hline LPC & $1.880 \pm 0.35^{b}$ & $2.180 \pm 0.15^{b}$ & $2.030 \pm 0.32^{a b}$ & $2.060 \pm 0.35^{a b}$ & 2. $240 \pm 0.10^{\circ}$ & 2. $150 \pm 0.15^{\mathrm{ab}}$ & $2.160 \pm 0.15^{\mathrm{ab}}$ & $18.93^{*}$ & .004 & $\mathrm{~K}-\mathrm{W}$ \\
\hline $\mathrm{CCV}$ & $1 / 840 \pm 0.36$ & $2.080 \pm 0.12$ & $2.060 \pm 0.17$ & $2.000 \pm 0.16$ & & & & 9.1 & 0.1 & $\mathrm{~K}-\mathrm{W}$ \\
\hline $\mathrm{GCV}$ & $1.920 \pm 0.34^{2}$ & $1.360 \pm 0.38^{b}$ & $1.330 \pm 0.52^{b}$ & $1.310 \pm 0.44^{b}$ & $1.230 \pm 0.23^{b}$ & $1.270 \pm 0.37^{b}$ & $1.440 \pm 0.44^{b}$ & $21.87^{\circ}$ & 0.001 & $\mathrm{~K}-\mathrm{W}$ \\
\hline PSH2 & $2.010 \pm 0.30$ & $1.990 \pm 0.13$ & $1.910 \pm 0.47$ & $1.930 \pm 0.29$ & $1.980 \pm 0.13$ & $1.920 \pm 0.16$ & $1.860 \pm 0.31$ & 6.27 & 0.394 & $\mathrm{~K}-\mathrm{W}$ \\
\hline PSH6 & $1.760 \pm 0.28$ & $1.900 \pm 0.12$ & $1.750 \pm 0.40$ & $1.870 \pm 0.15$ & $1.770 \pm 0.26$ & $1.830 \pm 0.16$ & $1.830 \pm 0.24$ & 3.66 & 0.723 & GLM \\
\hline NT6 & $2.240 \pm 1.09^{b}$ & $2.730 \pm 0.78^{\mathrm{ab}}$ & $3.120 \pm 0.26^{2}$ & $3.050 \pm 0.27^{\mathrm{a}}$ & $2.940 \pm 0.26^{*}$ & $2.920 \pm 0.34^{4 b}$ & $2.720 \pm 0.76^{a b}$ & $16.21^{\circ}$ & 0.013 & $\mathrm{~K}-\mathrm{W}$ \\
\hline NT5 & $2.410 \pm 1.17$ & $3.010 \pm 0.29$ & $3.070 \pm 0.32$ & $2.860 \pm 0.77$ & $3.050 \pm 0.26$ & $2.730 \pm 0.87$ & $2.890 \pm 0.30$ & 5.55 & 0.475 & $\mathrm{~K}-\mathrm{W}$ \\
\hline NTS & $1.740 \pm 0.14$ & $1.740 \pm 0.16$ & $1.650 \pm 0.23$ & $1.590 \pm 0.26$ & $1.720 \pm$ & $1.620 \pm 0.21$ & & 6.23 & 0.398 & $\mathrm{~K}-\mathrm{W}$ \\
\hline $\mathrm{MM}$ & $0.760 \pm 0.51^{2}$ & $0.430 \pm 0.32^{a b}$ & $0.470 \pm 0.30^{a b}$ & $0.360 \pm 0.17^{b}$ & $0.320 \pm 0.08^{\circ}$ & $0.420 \pm 0.27^{\mathrm{ab}}$ & $0.390 \pm 0.18^{a b}$ & $13.68^{\circ}$ & 0.033 & $\mathrm{~K}-\mathrm{W}$ \\
\hline $\mathrm{AL}$ & $0.590 \pm 0.37$ & $0.830 \pm 0.48$ & $0.710 \pm 0.45$ & $0.820 \pm 0.51$ & $0.810 \pm 0.41$ & $0.870 \pm 0.58$ & $0.690 \pm 0.54$ & 3.55 & 0.737 & $\mathrm{~K}-\mathrm{W}$ \\
\hline \multicolumn{11}{|c|}{$\begin{array}{l}\text { SLO: The slope, TEM: The temperature, HUM: The humidity, LUX: The light intensity, NDT: The number of dead trees, DDT: The d.b.h of dead } \\
\text { trees, NPT: The number of palm trees, LDP: The leaf litter depth, LPC: The leaf litter cover, BSL: The basal area, CCV: The canopy cover, } \\
\text { GCV: The ground cover, SHC: The under storey shrub cover, PSH2: The percent of shrub cover between } 0.5 \text { and } 2 \mathrm{~m} \text { high, PSH6: The percent of } \\
\text { shrub cover between } 2 \text { and } 6 \mathrm{~m} \text { high, NT6: The number of trees } 6-10 \mathrm{~m} \text { high, NT } 10 \text { : The number of trees higher than } 10 \mathrm{~m}, \text { NT2: The number of } \\
\text { tree saplings with d.b.h less than } 2 \mathrm{~cm} \text {, NT5: The number of trees with d.b.h } 5-10 \mathrm{~cm}, \text { NTS: The number of tree species, NT20: The number of tree } \\
\text { with d.b.h } 20-30 \mathrm{~cm}, \text { NT30: The number of tree with d.b.h } 30-50 \mathrm{~cm}, \text { NT50: The number of tree with d.b.h more than } 50 \mathrm{~cm}, \text { MM: The number of } \\
\text { Melastoma malabathricum shrubs and AL: The number of Agrastistachys longifolia trees. Different means with different letters are significantly } \\
\text { different *Significant at } \alpha=0.05\end{array}$} \\
\hline
\end{tabular}

Table 4: Results of stepwise multiple regression models for abundance of insectivorous sub-guilds and 25 insectivorous species related to environmental variables

\begin{tabular}{|c|c|c|c|}
\hline Guilds and species & Regression & $\mathrm{R}^{2}$ & p-value \\
\hline Terrestrial insectivores & $\mathrm{N}=-39.174+0.4391 \mathrm{X}_{14}+0.414 \mathrm{X}_{4}+\mathrm{X}_{8}+0.034 \mathrm{X}_{12}$ & 0.508 & 0.027 \\
\hline Sallying insectivores & $\mathrm{N}=42.892-1.618 \mathrm{X}_{3}-0.195 \mathrm{X}_{1}$ & 0.151 & 0.037 \\
\hline Bark-gleaning insectivores & $\mathrm{N}=-21.557-0.202 \mathrm{X}_{2}+0.255 \mathrm{X}_{4}$ & 0.12 & 0.020 \\
\hline Arboreal foliage gleaning insectiv ores & $\mathrm{N}=20.122-0.085 \mathrm{X}_{16}-0.005 \mathrm{X}_{1}-2.185 \mathrm{X}_{22}-0.006 \mathrm{X}_{11}-0.227 \mathrm{X}_{25}$ & 0.362 & 0.046 \\
\hline Black-caped Babbler & $N=-0.005+X$ & 0.048 & 0.035 \\
\hline Short-tailed Babbler & $\mathrm{N}=-31.356+0.428 \mathrm{X}_{14}+0.311 \mathrm{X}_{4}+0.001 \mathrm{X}_{1}+0.018 \mathrm{X}_{17}+0.029 \mathrm{X}_{12}$ & 0.582 & 0.023 \\
\hline Magpie Robin & $N=0.88+X_{1}+0.001 X_{10}+X_{9}-0.007 X_{17}$ & 0.212 & 0.047 \\
\hline Greater Racket-tailed Drongo & $N=-20.659+0.243 X_{4}-0.188 X_{2}+X_{13}$ & 0.149 & 0.025 \\
\hline Dark-sided Flycatcher & $\mathrm{N}=-0.009+0.008 \mathrm{X}_{17}+\mathrm{X}_{13}$ & 0.158 & 0.011 \\
\hline Dusky Broadbill & $N=3.025-0.008 X_{25}-0.1 X_{22}+0.003 X_{17}-0.126 X_{3}$ & 0.281 & 0.031 \\
\hline Golden-bellied Greygone & $\mathrm{N}=-0.012+0.033 \mathrm{X}_{21}$ & 0.077 & 0.007 \\
\hline Pied Fantail & $N=-0.214+0.001 X_{11}+X_{5}+0.003 X_{16}-0.006 X_{12}$ & 0.364 & 0.016 \\
\hline Banded Woodpecker & $\mathrm{N}=0.406+0.02 \mathrm{X}_{19}$ & 0.054 & 0.025 \\
\hline Buff-necked Woodpecker & $\mathrm{N}=0.67-0.078 \mathrm{X}_{2}$ & 0.077 & 0.007 \\
\hline Checker-throated Woodpecker & $N=0.491-0.021 X_{20}$ & 0.047 & 0.036 \\
\hline Greater Yellownape & $N=-0.36+X_{9}$ & 0.045 & 0.04 \\
\hline Chestnut-winged Babbler & $N=-13.437-0.065 X_{20}+0.158 X_{4}-0.313 X_{12}$ & 0.195 & 0.028 \\
\hline Striped Tit-babbler & $\mathrm{N}=4.216-0.002 \mathrm{X}_{1}+0.03 \mathrm{X}_{17}-0.298 \mathrm{X}_{25}+0.001 \mathrm{X}_{7}-0.003 \mathrm{X}_{10}+0.037 \mathrm{X}_{18}$ & 0.391 & 0.038 \\
\hline Fluffy-backed Tit-babbler & $\mathrm{N}=3.022-0.020 \mathrm{X}_{16}-1.243 \mathrm{X}_{26}+\mathrm{X}_{1}+\mathrm{X}_{10}$ & 0.279 & 0.027 \\
\hline Grey-headed Babbler & $\mathrm{N}=-0.006+0.058 \mathrm{X}_{24}$ & 0.287 & 0.000 \\
\hline Scaly-crowned Babbler & $N=-0.08+0.015 X_{14}+0.003 X_{12}$ & 0.106 & 0.020 \\
\hline Rufous-crowned Babbler & $\mathrm{N}=8.999-0.015 \mathrm{X}_{15}-0.315 \mathrm{X}_{3}$ & 0.208 & 0.020 \\
\hline Moustached Babbler & $\mathrm{N}=0.039-0.018 \mathrm{X}_{2}+0.106 \mathrm{X}_{23}+\mathrm{X}_{1}$ & 0.380 & 0.048 \\
\hline Plaintive Cuckoo & $\mathrm{N}=-0.329+\mathrm{X}_{13}+0.008 \mathrm{X}_{18}+0.11 \mathrm{X}_{12}$ & 0.226 & 0.027 \\
\hline Drongo Cuckoo & $N=0.081+X_{s}+X_{11}$ & 0.112 & 0.025 \\
\hline Indian Cuckoo & $N=0.205+X_{1}+0.083 X_{21}+X_{5}+X_{41}$ & 0.311 & 0.032 \\
\hline White-rumped Shama & $N=0.197+0.001 X_{10}+X_{7}$ & 0.141 & 0.022 \\
\hline Common tailorbird & $N=3.059-0.025 X_{10}+X_{10}-0.414 X_{22}$ & 0.154 & 0.047 \\
\hline
\end{tabular}

\begin{tabular}{llll} 
Common tailorbird & $\mathrm{N}=3.059-0.025 X_{10}+X_{10}-0.414 X_{23}$ & 0.154 & 0.047 \\
\hline
\end{tabular}

Only insectivorous species that had a significant relationship with habitat variables are shown. $X_{1}$ : Distance from the forest edge; $X_{1}$ : Slope; $\mathrm{X}_{3}$ : Temperature; $\mathrm{X}_{4}$ : Humidity, $\mathrm{X}_{3}$ : Density of trees between $6-10 \mathrm{~m}$ height ha ${ }^{-1} ; \mathrm{X}_{\mathrm{r}}$ : Density of trees higher than $10 \mathrm{~m} \mathrm{ha}^{-1}$; $\mathrm{X}_{\mathrm{g}}$ : Density of tree saplings with $\mathrm{DBH}$ less than $2 \mathrm{~cm} \mathrm{ha}^{-1}, \mathrm{X}_{6}$ : Density of tree saplings with DBH $2-5 \mathrm{~cm} \mathrm{ha}^{-1}$; $\mathrm{X}_{9}$. Density of tree with DBH $5.1-10 \mathrm{~cm} \mathrm{ha}^{-1} ; \mathrm{X}_{10}$ Density of palms ha ${ }^{-1}, X_{11}$ : Density of dead trees ha ${ }^{-1}, X_{12}$ : D.B.H of dead trees $(\mathrm{cm}) ; X_{13}$ : Density of shrubs ha; ${ }^{-1} X_{14}$ : Leaf litter depth $(\mathrm{cm}) ; X_{11}:$ Leaf litter cover (\%); $X_{11}$ : Canopy cover (\%); $X_{17}$. Percentage of ground cover, $X_{18}$ : Percentage of shrub cover between 0.5 and $2 \mathrm{~m}$ high; $X_{19}$ : Percentage of shrub cover between 2 and $6 \mathrm{~m}$ high; $\mathrm{X}_{20}$ : Number of tree species, $\mathrm{X}_{21}$ : Density of tree with DBH $20.1-30 \mathrm{~cm}^{-1} ; \mathrm{X}_{12}$ : Density of tree with DBH $30.1-50 \mathrm{~cm} \mathrm{ha}^{-1}, \mathrm{X}_{23}$ : Density of tree with DBH more than $50 \mathrm{~cm} \mathrm{ha}^{-1} ; \mathrm{X}_{24}$ : Number of Melastoma malabathricum shrubs ha ${ }^{-1}$; $\mathrm{X}_{25}:$ Number of Agrostistachys longifolia trees $\mathrm{ha}^{-1}, \mathrm{X}_{26}$ : Basal area $\mathrm{m}^{2} \mathrm{ha}^{-1}$ 
positively correlated with leaf litter depth, humidity, density of tree sapling with d.b.h $2-5 \mathrm{~cm} \mathrm{ha}^{-1}$ and d.b.h of dead trees. Sallying insectivores was negatively correlated with temperature and slope. Bark gleaning insectivores was negatively correlated with slope and positively correlated with humidity. The canopy cover, distance from the forest edge, the density of tree with d.b.h $30.1-50 \mathrm{~cm} \mathrm{ha}^{-1}$, the density of dead trees/ha and the number of Agrostistachys longifolia trees/ha were negative predictors for Arboreal foliage gleaning insectivores.

At the species level, 24 insectivorous species abundances could be related to environmental variables. Seven of these species equation included a single variable (Table 4). The distance from the forest edge was correlated with the abundances of short-tailed babbler, striped Tit-babbler, fluffybacked Tit-babbler, moustached babbler (Malacopteron magnirostre), magpie robin (Copsychus saularis) and Indian Cuckoo (Cuculus micropterus). Humidity and temperature as climatic variables were environmental variables that influenced some of under storey insectivores (Table 3 ). There was also positive relationship between humidity and the abundances of Short-tailed Babbler, Chestnut-winged Babbler (Stachyris erythroptera) and Greater Racket-tailed Drongo (Dicrurus paradiseus). Temperature was a significant and negative predictor for Dusky Broadbill (Corydon sumatranus) and Rufous-crowned Babbler (Malacopteron magnum). The slope showed a negative relationship with abundances of Greater Racket-tailed Drongo, Buff-necked Woodpecker (Meiglyptes tukki) and Moustached Babbler (Table 4).

\section{Community Analysis}

To describe how individual Insectivorous species are distributed with respect to environmental variables, the linear constrained redundancy ordination (RDA) was performed. There was a strong relationship between environmental variables and insectivorous species abundance. The total ordination of species along environmental variable gradients was significant $(p=0.010$, Monte Carlo simulations at 499 permutations). The first two axes explained $61 \%$ of the variation in the species data that can be explained with the environmental explanatory variables. The first two axes explained $56 \%$ of this, which works out as $34.16 \%$ of the insectivorous species variables. Species-environment correlations for the first two axes were 0.73 and 0.74 . These correlations measure how well environmental variables explain the extracted variation in community composition.

Environmental variables differed in their relation to the first and second axes of RDA ordination (Fig. 2). The first access represented the vegetation and distance gradient. Environmental variables significantly related with this axes were: light intensity, shrub cover, the percent of shrub cover between 0.5 and $2 \mathrm{~m}$ high, the ground cover, the number of Agrostistachys longifolia trees, the leaf litter cover, the slop, the canopy cover, the number of palm trees, the number of dead trees, the number of trees with d.b.h $30-50 \mathrm{~cm}$ and distance from the forest edge. The second axes represented a microclimate gradient including humidity and temperature.

The first axis, describing vegetation and distance gradient, successfully separated two groups of insectivorous birds. Group A (terrestrial insectivores) in the positive direction with distance from the forest edge at the left side of ordination diagram from group B (arboreal foliage gleaning insectivores) in the negative direction with distance from the forest edge at the right side of ordination diagram (Fig. 2).

The RDA ordination biplot (Fig. 2) indicated that terrestrial insectivores was positively correlated with the distance gradient, the humidity, the litter percent, the canopy cover, the number of tree with d.b.h $30-50 \mathrm{~cm}$ and the number of palm trees (hereafter edge-avoider guild). On the contrary, arboreal foliage gleaning insectivores was positively correlated with the ground cover, the light intensity, the shrub cover and the percent of shrub cover between 0.5 and $2 \mathrm{~m}$ high (hereafter edge-tolerant guild). This group was negatively correlated with distance from the forest edge. Sallying insectivores and Bark gleaning insectivores showed no significant bias towards or against distance gradient (hereafter ubiquitous guilds). Some species of these two guilds showed tendency to the edge 


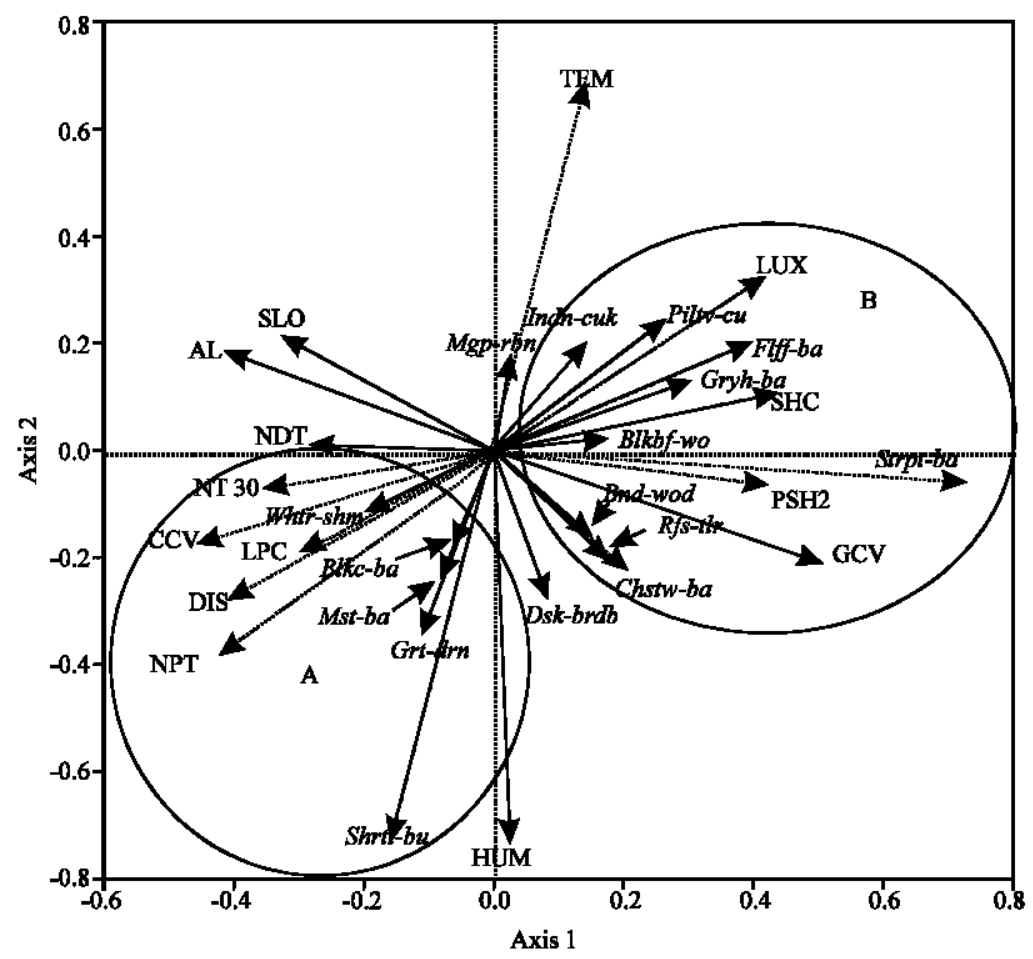

Fig. 2: Ordination diagram of the first two axes of RDA for under storey insectivores and all environmental variables in Ayer Hitam Forest Reserve. Axis 1 and 2 accounted for 27.45 and $6.71 \%$ of the variance in the species data. Arrows represent directions to greatest change of variables. Environmental variables: LUX: The light intensity, TEM: The temperature, SHC: The shrub cover, PSH2: The percent of shrub cover between 0.5 and $2 \mathrm{~m}$ high, GCV: The ground cover, HUM: The humidity, DIS: The distance from the edge forest, NPT: The number of palm trees, CCV: The canopy cover, SLO: The slop, LPC: The leaf litter cover, AL: The number of Agrostistachys longifolia trees, NT30: The number of tree with d.b.h $30-50 \mathrm{~cm}$, NDT: The number of dead trees. Insectivorous bird species: (Plntv-cu) Plaintive Cuckoo, (Indn-cuk) Indian Cuckoo, (Mgp-rbn) Magpie Robin, (Flff-ba) Fluffy-backed Tit-babbler, (Gryh-ba) Grey-headed Babbler, (Strpt-ba) Striped Tit-babbler, (Bnd-wod) Banded Woodpecker, (Rfs-tlr) Rufous-tailed Tailorbird, (Chstw-ba) Chestnut-winged Babbler, (Shrtt-ba) Short-tailed Babbler, (Dsk-brdb) Dusky Broadbill, (Grt-drn) Greater Racket-tailed Drongo, (Mst-ba) Moustached Babbler, (Blkc-ba) Black-caped Babbler, (Whtr-shm) White-rumped Shama

such as Banded Woodpecker (Picus mineaceus), Dusky Broadbill and some of them tendency to the interior such as Greater Racket-tailed Drongo.

To determine which explanatory variables are most important, a forward selection procedure was applied (Fig. 3). The forward selection procedure indicated that the ground cover, the percent of shrub cover between 0.5 and $2 \mathrm{~m}$ high, the humidity, the distance from the forest edge, the number of Agrostistachys longifolia trees and the number of palm trees are most important explanatory variables describing insectivorous species composition. 


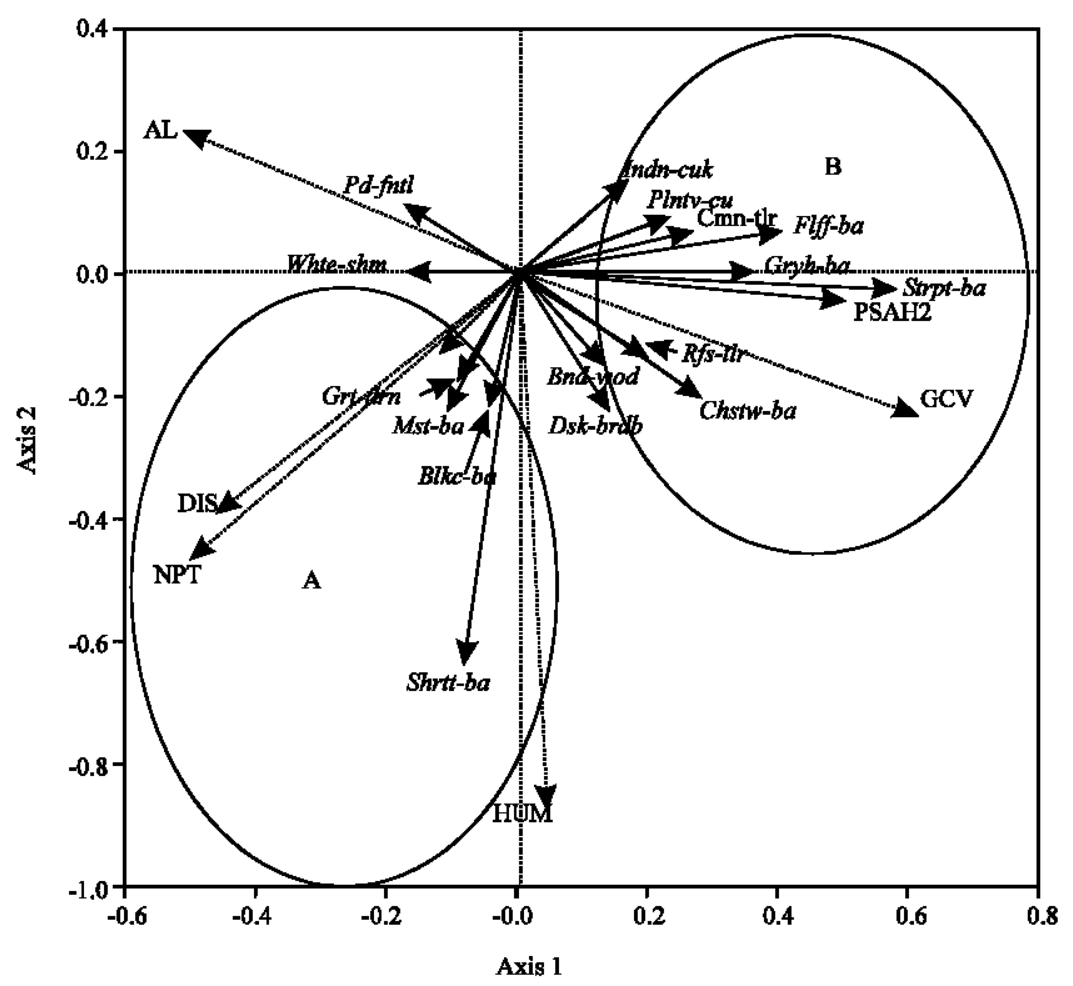

Fig. 3: Ordination diagram of the first two axes of RDA for under storey insectivores and important environmental variables in Ayer Hitam Forest Reserve. Axis 1 and 2 accounted for 6.8 and $1.9 \%$ of the variance in the species data. Arrows represent directions of greatest change of variables. Environmental variables: PSH2: The percent of shrub cover between 0.5 and $2 \mathrm{~m}$ high, GCV: The ground cover, HUM: The humidity, DIS: The distance from the edge forest, NPT: The number of palm trees, AL: The number of Agrostistachys longifolia trees. Insectivorous bird species: (Plntv-cu) Plaintive Cuckoo, (Indn-cuk) Indian Cuckoo, (Flff-ba) Fluffy-backed Tit-babbler, (Gryh-ba) Grey-headed Babbler, (Strpt-ba) Striped Tit-babbler, (Bnd-wod) Banded Woodpecker, (Rfs-tlr) Rufous-tailed Tailorbird, (Chstw-ba) Chestnutwinged Babbler, (Shrtt-ba) Short-tailed Babbler, (Dsk-brdb) Dusky Broadbill, (Grt-drn) Greater Racket-tailed Drongo, (Mst-ba) Moustached Babbler, (Blkc-ba) Black-caped Babbler, (Whtrshm) White-rumped Shama, (Sclyc-ba) Scaly-crowned Babbler, (Pd-fntl) Pied fantail, (Cmn-tlr) Common tailorbird

To display the variability in the insectivorous species composition (diversity index values) related to explanatory variables along edge-interior gradient, the biplot diagrams with the most important environmental variables and plots by using the default values for the loess method (isoline) corresponding to species diversity indices were plotted (Fig. 4). The Simpson and Shannon-Wiener diversity indices were positively correlated with humidity, distance from the forest edge and the number of palm trees and negatively correlated with ground cover, percent of shrub cover between 0.5 and $2 \mathrm{~m}$ high and the number of Agrostistachys longifolia trees (Fig. 4a, b). Moreover, the Simpson evenness index was negatively correlated with humidity, distance from the forest edge, ground cover, percent of shrub cover between 0.5 and $2 \mathrm{~m}$ high and the number of palm trees and positively correlated with the number of Agrostistachys longifolia trees (Fig. 4c). 

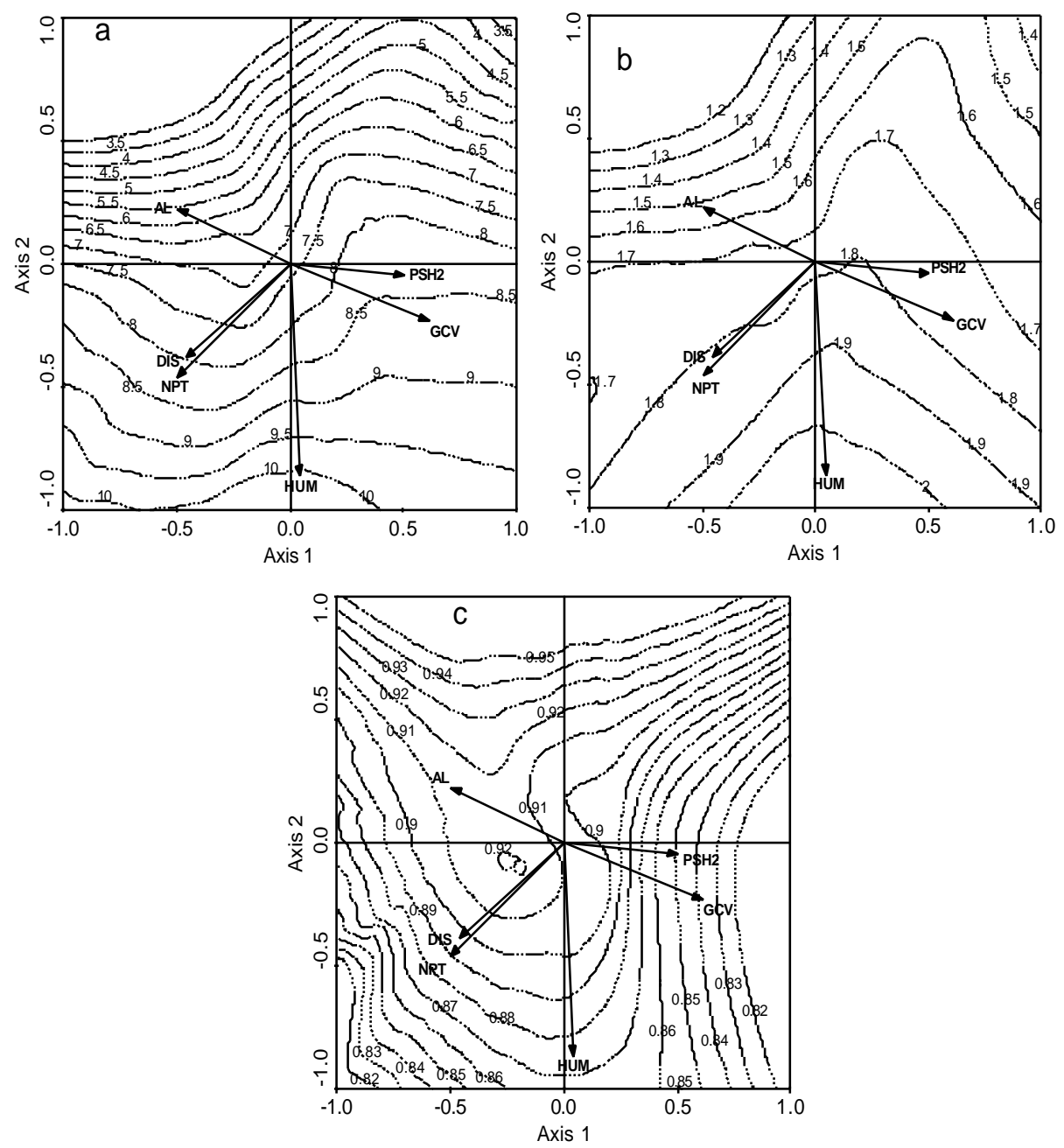

Fig. 4: The isolines of insectivorous species diversity of samples with the most important environmental variables, plotted in the RDA ordination diagram. (a) Number of insectivorous species, (b) Shannon-Wiener diversity index, (C) Simpson evenness index. The numbers corresponds to the value of species diversity indices on the isolines. (AL) the number of Agrostistachys longifolia trees, (NPT) the number of palm trees, (DIS) the distance from the edge forest, (HUM) the humidity, (GCV) the ground cover, (PSH2) the percent of shrub cover between 0.5 and $2 \mathrm{~m}$ high

\section{DISCUSSION}

The main objective of this study was to test the effects of the edge-interior gradient on the abundance, density and diversity of under storey insectivores and to correlate these effects with environmental variables at the population and community levels. There was no effect of distance gradient on the insectivorous bird abundance. Among the four insectivore sub-guilds, two showed a significant difference in the numbers observed. Terrestrial insectivores had a significantly higher number 
in distances 6 and 7 while arboreal foliage gleaning insectivores had a significantly higher number in distance 1. There was also significant effect of distance from the forest edge at the species level. Among the 49 under storey insectivores, five showed a significant difference in the numbers observed. Three insectivorous species for which abundance was significantly high close to the edge were Striped Tit-babbler, Fluffy-backed Tit-babbler and Plaintive Cuckoo. Two insectivorous species for which abundance increased significantly with increasing distance from the forest edge were Short-tailed Babbler and White-rumped Shama. There was also strong effect of distances from the forest edge on the diversity indices. Shannon diversity index, Simpson diversity index and Simpson evenness index showed significant differences along edge-interior gradient. Forest interior habitat exhibited higher diversity indices than forest edge. The high values of Shannon and Simpson diversity indices and low value of Simpson evenness index at the forest interior was mainly a result of cooperation of some habitat variables such as humidity and the number of palm trees.

In this study, habitat quality along the edge-interior gradient was defined as a complex function of the 26 environmental variables was measured and that influenced insectivorous bird abundance and diversity (through RDA ordination). Edge effects for insectivorous birds were an indirect response to a cascade of effects that involved environmental variables of the microclimate and microhabitat. In Ayer Hitam Forest Reserve, the air temperature and light intensity tend to diminish from the forest edge to the interior while relative humidity tends to increase. Patterns of some microhabitat variables were also related to proximity to the forest edge. According to RDA ordination, the number of palm trees, leaf litter depth, the number of trees with d.b.h $30-50 \mathrm{~cm}$ and canopy cover were positively correlated with distance from the forest edge.

The RDA ordination separated two groups of insectivores. Terrestrial insectivores consist of species that occurred more abundant at the forest interior. These species are known to be especially abundant at the forest interior with high value of humidity, litter cover, canopy cover, the number of trees with d.b.h $30-50 \mathrm{~cm}$ and the number of palm trees. This group of insectivores have been suggested to be more vulnerable to the edge and open area (Lambert and Collar, 2002). Terrestrial insectivores such as Black-caped Babbler (Pellorneum capistratum), Black-throated Babbler (Napothera atrigularis) and Short-tailed Babbler are most adversely affected when their habitats are altered (Varasteh-Moradi et al., 2008). They are thought to be intolerant to high temperature or high light intensity (Zakaria et al., 2002). This shade-preferring group of insectivores (Varasteh-Moradi et al., 2008) tend to occupy the special microhabitat with high humidity, high leaf litter cover and dense canopy cover. Furthermore, they may avoid edge as they tend to have narrow diets, narrow ranges of tolerable environmental conditions and use specialized microhabitats that are not available at the forest edge (Lindell et al., 2004).

Arboreal foliage gleaning insectivores were positively correlated with ground cover, light intensity, shrub cover and percent of shrub cover between 0.5 and $2 \mathrm{~m}$ high (edge-tolerant). This group also was negatively correlated with distance from the forest edge. Among arboreal foliage gleaning insectivores, some species have been reported to increase in response to the edge and disturbance, such as the Tit babblers (Fimbel et al., 2001; Lambert, 1992). Sallying insectivores and Bark gleaning insectivores showed no significant bias towards or against distance gradient. One possible explanation for this is that they were mapping onto some unmeasured resources such as food. Some species of these two guilds showed tendency to the edge such as Banded Woodpecker, Dusky Broadbill and some of them tendency to the interior such as Greater Racket-tailed Drongo. Proximal explanations for edgeavoidance vary across system and species (Watson et al., 2004). For instance, habitat structure and composition may be different on the edge and microclimatic changes near the edge can make the edge unsuitable for some insectivores. In this study the edge habitat had significantly $(p<0.05)$ more shrub cover, ground cover, light intensity, temperature and less litter depth and humidity than the core 
habitat. Therefore, for terrestrial insectivores it is possible that the cause of their edge-sensitivity is due to a lack of a high humidity, dense canopy cover and deep litter depth at the edge.

Edge effects are a key component to understand how landscape structure influences habitat quality (Ries et al., 2004). Identifying the variables that affect the presence of insectivores in a given habitat is imperative in order to determine the threats that these species might be exposed along the edge-interior gradient. This will allow for the creation of robust tools for the conservation and management of species in isolated tropical forest. Present results suggest that under storey insectivorous species especially terrestrial insectivores are the most sensitive birds to edge effect. These species reflect the habitat quality of the forest interior and their disappearance may be an indication of habitat degradation within an isolated forest, or a fragmented and isolated forest is not large enough to exclude edge effects (Saetersdal et al., 2005). Forest remnants in the lowlands of Peninsular Malaysia that have a deep leaf litter layer, a dense canopy cover and high relative humidity are able to support insectivorous species that are sensitive to edge effects. As such these forests have important conservation value. These findings can assist wildlife managers in the selection of forest fragments appropriate for the preservation of bird species. It also is recommended that conservation strategies be applied to ensure that lowland rainforest remnants have a high area/perimeter ratio (to reduce edge effect) and to limit the destruction and degradation within the core of these larger remnants.

\section{ACKNOWLEDGMENTS}

We are grateful to all the people who have assisted us in the field during the data collection. This study was funded by the Research University Grand Scheme fund number 03/01/07/0043 RU.

\section{APPENDIX}

Appendix: The number of independent insectivorous bird observations based on visual cues in different distances from the forest edge in Ayer Hitam Forest Reserve

\begin{tabular}{|c|c|c|c|c|c|c|c|}
\hline \multirow[b]{2}{*}{ Insectivorous bird species } & \multicolumn{7}{|c|}{ Observations at different distances from edge (m) } \\
\hline & 25 & 200 & 400 & 600 & 800 & 1000 & 1200 \\
\hline Black-caped Babbler Pellorneum copistratum & 1 & 1 & 4 & 1 & 1 & 2 & 8 \\
\hline Black-throated Babbler Napothera atrigularis & 0 & 0 & 0 & 0 & 2 & 0 & 0 \\
\hline Short-tailed Babbler Malccocincla malaccensis & 15 & 19 & 34 & 22 & 29 & 34 & 43 \\
\hline Magpie Robin Copsychus saularis & 17 & 0 & 1 & 0 & 0 & 0 & 0 \\
\hline Siberian Blue Robin Luscinia cyane & 0 & 2 & 0 & 1 & 1 & 1 & 0 \\
\hline Hooded Pitta Pitta sordida & 0 & 0 & 0 & 0 & 0 & 1 & 0 \\
\hline Arctic Warbler Phylloscopus borealis & 0 & 0 & 0 & 0 & 0 & 0 & 1 \\
\hline Chestnut-winged Babbler Stachyris erythroptera & 9 & 15 & 12 & 17 & 12 & 9 & 6 \\
\hline Eyebrowed Wren-babbler Napothera epilepidota & 1 & 4 & 1 & 1 & 1 & 2 & 0 \\
\hline Fluffy-backed Tit-babbler Macronous ptilosus & 9 & 21 & 12 & 16 & 0 & 0 & 2 \\
\hline Gray-headed Babbler Stachyris poliocephala & 3 & 0 & 3 & 0 & 0 & 0 & 0 \\
\hline Moustached Babbler Malacopteron magnirostre & 0 & 1 & 0 & 0 & 0 & 1 & 2 \\
\hline Rufous-crowned Babbler Malacopteron magnum & 1 & 1 & 5 & 2 & 2 & 0 & 1 \\
\hline Scaly-crowned Babbler Molocopteron cinereum & 0 & 0 & 0 & 1 & 0 & 1 & 0 \\
\hline Striped Tit-babbler Macronous guloris & 106 & 43 & 65 & 56 & 39 & 22 & 43 \\
\hline White-bellied Yuhina Yuhina zontholeuca & 0 & 0 & 0 & 0 & 2 & 0 & 0 \\
\hline Banded Bay-cuckoo Cacomantis sonneratii & 0 & 0 & 1 & 1 & 0 & 0 & 0 \\
\hline Drongo Cuckoo Surniculus lugubris & 1 & 3 & 0 & 0 & 0 & 0 & 0 \\
\hline Indian Cuckoo Cuculus micropterus & 4 & 5 & 1 & 0 & 0 & 0 & 0 \\
\hline Plaintive Cuckoo Cacomantis merulinus & 12 & 6 & 2 & 2 & 0 & 2 & 4 \\
\hline Common Tailorbird Orthotomus sutorius & 24 & 24 & 28 & 18 & 14 & 19 & 15 \\
\hline Dark-necked Tailorbird Orthotomus atroguloris & 3 & 2 & 4 & 0 & 1 & 0 & 3 \\
\hline
\end{tabular}




\begin{tabular}{llllllll}
\hline & Observations at different & distances from & edge (m) \\
Insectivorous bird species & 25 & 200 & 400 & 600 & 800 & 1000 & 1200 \\
\hline Rufous-tailed Tailorbird Orthotomus sericeus & 0 & 0 & 1 & 0 & 0 & 0 & 0 \\
Oriental White-eyed Zosterops palpebrosus & 2 & 0 & 0 & 0 & 0 & 0 & 0 \\
White-rumped Shama Copsychus malabaricus & 8 & 15 & 21 & 6 & 7 & 4 & 5 \\
Banded Woodpecker Picus mineaceus & 12 & 20 & 23 & 12 & 13 & 12 & 12 \\
Black and buff Woodpecker Meiglyptes jugularis & 1 & 0 & 0 & 0 & 0 & 0 & 0 \\
Buff-necked Woodpecker Meiglyptes tukki & 7 & 3 & 7 & 4 & 6 & 2 & 3 \\
Checker-throated Woodpecker Picus mentalis & 3 & 2 & 4 & 0 & 2 & 4 & 4 \\
Common Flameback Woodpecker Dinopium javanense & 0 & 0 & 0 & 1 & 0 & 0 & 0 \\
Crimson-winged Woodpecker Picus puniceus & 0 & 2 & 0 & 0 & 0 & 0 & 0 \\
Greater Flameback Chrysocoloptes lucidus & 0 & 1 & 2 & 0 & 0 & 0 & 0 \\
Greater Yellownape Picus flavinucha & 2 & 8 & 1 & 1 & 1 & 2 & 1 \\
Maroon Woodpecker Blythipicus rubiginosus & 2 & 10 & 2 & 3 & 4 & 3 & 11 \\
Olive-backed Woodpecker Dinopium raffesii & 0 & 0 & 0 & 1 & 0 & 0 & 0 \\
Asian Brown Flycatcher Muscicapa dauurica & 1 & 0 & 0 & 0 & 0 & 0 & 0 \\
Asian Paradise Fly catcher Terpsiphone paradisi & 0 & 1 & 2 & 1 & 1 & 0 & 0 \\
Black-naped Monarch Hypothymis azurea & 0 & 0 & 0 & 2 & 0 & 0 & 0 \\
Chestnut-winged Flycatcher Philentoma pyrhopterum & 0 & 0 & 6 & 4 & 0 & 1 & 1 \\
Dark-sided Fly catcher Muscicapa sibirica & 0 & 0 & 0 & 4 & 2 & 0 & 3 \\
Golden-bellied Gerygone Gerygone sulphurea & 0 & 1 & 0 & 0 & 0 & 0 & 0 \\
Green-backed Flycatcher Ficedula elisae & 0 & 0 & 0 & 2 & 0 & 0 & 1 \\
Grey-headed Canary Fly catcher Culicicapa ceylonensis & 0 & 0 & 0 & 2 & 0 & 0 & 1 \\
Bronzed Drongo Dicrurus aeneus & 0 & 1 & 0 & 1 & 0 & 0 & 2 \\
Crow-billed Drongo Dicrurus annectons & 2 & 0 & 2 & 0 & 2 & 1 & 1 \\
Greater Racket-tailed Drongo Dicrurus paradise us & 19 & 28 & 34 & 30 & 27 & 18 & 17 \\
Lesser Racket-tailed Drongo Dicrurus remifer & 1 & 2 & 3 & 1 & 0 & 1 & 0 \\
Dusky Broadbill Corydon sumatranus & 2 & 0 & 2 & 1 & 3 & 0 & 1 \\
Pied Fantail Rhipidura javanica & 1 & 3 & 0 & 0 & 0 & 0 & 0 \\
\hline
\end{tabular}

\section{REFERENCES}

Antongiovanni, M. and J.P. Metzer, 2005. Influence of matrix habitats on the occurrence of insectivorous bird species in Amazonian forest fragments. Biol. Conservat., 122: 441-451.

Barlow, J. and C.A. Peres, 2004. Avifaunal responses to single and recurrent wildfires in Amazonian forests. Ecol. Appli., 14: 1358-1373.

Bibby, C.J., N.D. Burgess and D.A. Hill, 2000. Bird Census Techniques. 2nd Edn., Academic Press, London, ISBN: 0120958317.

Canaday, C., 1996. Loss of insectivorous birds along a gradient of human impact in Amazonia. Biol. Conservat., 77: 63-77.

Castelletta, M., J.M. Thiollay and N.S. Sodhi, 2005. The effects of extreme forest fragmentation on the bird community of Singapore Island. Biol. Conservat., 121: 135-155.

Donovan, T.M., P.W. Jones, E.M. Annand and F.R. Thompson III, 1997. Variation in local-scale edge effects: Mechanisms and landscape context. Ecology, 78: 2064-2075.

Fimbel, R.A., A. Grajal and J.G. Robinson, 2001. The Cutting Edge (Conservation Wildlife in Logged Tropical Forest). 1st Edn., Colombia University Press, New York, ISBN: 81-211-0431-9.

Hill, J.K. and K. Hamer, 2004. Determining impacts of habitat modification on diversity of tropical forest fauna: The importance of spatial scale. J. Applied Ecol., 41: 744-754.

Jongman, R.R., C.J.F. Ter Braak and O.F.R. Van Tongeren, 1995. Data Analysis in Community and Landscape Ecology. 2nd Edn., Cambridge University Press, Cambridge, UK., ISBN: 0521475740. Lambert, F.R., 1992. The consequences of selective logging for Bornean lowland forest birds. Phil. Trans. Roy. Soc., 335: 443-457. 
Lambert, F.R. and N.J. Collar, 2002. The future for Sundaic lowland forest birds: Long-term effects of commercial logging and fragmentation. Forktail, 18: 127-146.

Lidicker, W.Z., 1999. Responses of mammals to habitat edges: An overview. Landscape Ecol., 14: 333-343.

Lindell, C.A., W.H. Chomentowski and J.R. Zook, 2004. Characteristics of bird species using forest and agricultural land covers in Southern Costa Rica. Biodiver. Coservat., 13: 2419-2441.

Maina, G.G. and W.M. Jackson, 2003. Effects of fragmentation on artificial nest predation in a tropical forest in Kenya. Biol. Conservat., 111: 161-169.

Marsden, S.J., M. Whiffin and M. Galetti, 2001. Bird diversity and abundance in forest fragments and Eucalyptus plantations around an Atlantic forest reserve, Brazil. Biodiver. Conservat., 10: 737-751.

Paton, P.W., 1994. The effect of edge on avian nest success: How strong is the evidence? Conservat. Biol., 8: 17-26.

Ries, L., R.J. Fletcher, J. Battin and T.D. Sisk, 2004. Ecological responses to habitat edges: Mechanisms, models and variability explained. Ann. Rev. Ecol. Evol. Syst., 35: 491-522.

Saetersdal, M., I. Gjerde and H.H. Blom, 2005. Indicator species and the problem of special inconsistency in nestedness patterns. Biol. Conservat., 122: 305-316.

Sisk, T.D., N.M. Haddad and P.R. Ehrilch, 1997. Bird assemblages in patchy woodlands: Modelling the effects of edge and matrix habitats. Ecol. Appli., 7: 1170-1180.

Soh, M., N.S. Sodhi and S.L.H. Lim, 2005. High sensitivity of montane bird communities to habitat disturbance in Peninsular Malaysia lowland rainforest. Biol. Conservat., 85: 199-202.

Stephens, S.E., D.N. Koons, J.J. Rotella and D.W. Willet, 2003. Effects of habitat fragmentation on avian nesting success: A review of the evidence at multiple spatial scales. Biol. Conservat., 115: 101-110.

Ter-Braak, C.J.F. and P. Smilauer, 2002. Canoco refrence manual and cano draw for windows user's guide: Software for canonical ordination (version 4.5). Report Microcomputer Power. Ithaca, NY., USA.

Varasteh-Moradi, H., M. Zakaria and Z. Rosli, 2008. Comparison of bird species composition in relation to different disturbance level in a tropical lowland rain forest in Peninsular Malaysia. Malaysian For., 71: 173-186.

Watson, J.E.M., R.J. Whittaker and T.P. Dawson, 2004. Habitat structure and proximity to forest edge affect the abundance and distribution of forest-dependent birds in tropical coastal forests of Southeastern Madagascar. Biol. Conservat., 120: 311-327.

Woodroffe, R. and J.R. Ginsberg, 1998. Edge effects and the extinction of populations inside protected areas. Science, 280: 2126-2128.

Zakaria, M., A. Khairul and N. Jamalun, 2002. Comparison of under storey bird species composition in a primary and logged mixed hill dipterocarp forest in Peninsular Malaysia. Malayan Nature J., 19: 74-85.

Zanette, L., P. Doyle and S.M. Trmont, 2000. Food shortage in small fragments: Evidence from an area-sensitive passerine. Ecology, 81: 1654-1666.

Zuur, A.F., E.N. Ieno and G.M. Smith, 2007. Analyzing Ecological Data. 1st Edn., Springer Science and Business Media, LLC, New York, ISBN: 0-387-45967-7. 